\title{
THE ADOPTION OF BIG DATA SERVICES BY MANUFACTURING FIRMS: AN EMPIRICAL INVESTIGATION IN INDIA
}

\author{
Surabhi Verma \\ National Institute of Industrial Engineering, India
}

\begin{abstract}
Although some leading companies are actively adopting Big data services (BDS) to strengthen market competition, many manufacturing firms are still in the early stage of the adoption curve due to lack of understanding of and experience with BDS. Hence, it is interesting and timely to understand issues relevant to BDS adoption. The empirical investigation reveals that a firm's intention to adopt BDS can be positively affected by the quality and benefits of BDS. Surprisingly, a firm's absorptive capacity in utilizing big data and risks and costs associated with implementation and maintenance does not impact the adoption intention of BDS.
\end{abstract}

Keyword: Big Data Services, Adoption intention, Manufacturing firms, Information Technology

\section{INTRODUCTION}

Big data services have created a new computational paradigm shift in data system architecture across horizontally-coupled resources to achieve the scalability needed for the efficient processing of extensive datasets (Anderson, 2008; Mayer Schönberger \& Cukier, 2013; Weinberger, 2012). This is exactly how big data services differs from typical information system (IT). It is a technological innovation where complex unstructured and structured data are parallel distributed, stored and direct queries could be applied to these stored data (Puschmann and Burgess, 2014). Through big data services, an enterprise could better monitor the acceptance of products/services in the marketplace and in understanding its business environment, potentially fueling competitive advantages (Davenport, 2012). Big data services have potential to unleash major impacts on reducing business costs, kindling business insights, and unraveling strategic information, and subsequently boosting quality and effectiveness of corporate decision making (Chen et al., 2012; Kwon et al., 2014; Gandomi and Haider, 2015). Service providing sectors like telecommunication, banking and finance, IT companies, e-commerce and more have quickly adopted this big data bandwagon (Chen and Zhang, 2014). However, many manufacturing firms are still sitting on the fence and are contemplating whether to move or not to adopt the big data trend (Dubey et al., 2015). This may be due to a lack of understanding of benefits of big data services in manufacturing sector, skills and experience in handling the big data. The situation

Manuscript first received/Recebido em: 2017/03/17 Manuscript accepted/Aprovado em: 2017/04/17 
points to the need for more research to comprehend issues (e.g., data quality, perceived costs) pertaining to big data services adoption in manufacturing sector.

The literature review reveals that many studies were (and currently are being) conducted on the use of big data services by enterprises primarily on their perceptions about benefits, costs and data quality (Kwon et al., 2014; Shin, 2015). The major contribution of this research paper is to identify new factors as well as to develop a sense of the relative weight of existing factors like perceived benefits and perceived costs of big data services, absorptive capacity and big data quality on manufacturing firms approach toward usage and adoption of big data for their businesses. In addition, very limited research or literature has been found yet on this research topic in any developing country. This research study reveals the perceptions as well as the intentions of the manufacturing firms toward factors like perceived benefits, perceived cost, absorptive capacity and big data quality in a quantitative manner, which are quite different as perceived by the worldwide big data community especially in manufacturing enterprises. This research captured the actual decisions taken by the respondents rather than merely the eagerness and intention to adopt big data services. For practical reasons, this study focuses on the manufacturing companies in India. The rest of this paper is organized as follows: Section 2 discusses the relevant and recent literature reviewed for this research study. Section 3 outlines the research methodology and Section 4 discuss the empirical findings and presents the conceptual model and experimental hypothesis on which the model is based. The subsequent sections describes the analysis of the data to validate the model. The implications for industry as well as for research and limitations and scope for future research have been discussed in last Sections 6, 7 and 8 respectively. The final Section 9 concludes the paper's results.

\section{SURVEY OF LITERATURE AND THEORETICAL DEVELOPMENT}

Earlier studies on big data have focused on technical and operational issues (Kwon et al., 2014). Not a single study has addressed the adoption of big data services from a manufacturing firms' perspective as depicted in Table 1. The additional value this research paper would add in helping manufacturing firms with their existing and forthcoming usage and adoption of big data services to enhance their ROI (return on investment). Through literature review it was found that most of studies are focused on assessing the direct effects of the innovation characteristics or the contextual factors. Table 1 illustrates that very few empirical study has conducted a holistic evaluation of the direct effects and the indirect effects of the determinants on big data services adoption. Motivated by these issues, this study seeks to develop a research model to understand the usage and adoption of big data services in manufacturing sector and direct and indirect impact of external factors on big data services adoption. 
JISTEM - Journal of Information Systems and Technology Management

Vol. 14, No. 1, Jan/Apr., 2017 pp. 39-68

ISSN online: $1807-1775$

DOI: $10.4301 / \mathrm{S} 1807-17752017000100003$

Table 1. Research studies on the usage and adoption of big data by firms.

\begin{tabular}{|c|c|c|c|c|}
\hline $\begin{array}{l}\text { IT adoption (dependent } \\
\text { variable) }\end{array}$ & $\begin{array}{l}\text { Constructs/factors } \\
\text { (independent variables) }\end{array}$ & Methods & $\begin{array}{l}\text { Data and } \\
\text { context }\end{array}$ & Author \\
\hline $\begin{array}{l}\text { Behavioral intention to } \\
\text { use big data services }\end{array}$ & $\begin{array}{l}\text { Big data system features } \\
\text { (Relative advantage, Quality, } \\
\text { Security, Inter-operability); } \\
\text { Perceived Value( Perceived } \\
\text { usefulness, Perceived ease of } \\
\text { use); implement intention }\end{array}$ & $\begin{array}{l}\text { Qualitative and } \\
\text { quantitative } \\
\text { methodology }\end{array}$ & $\begin{array}{l}\text { Survey of } \\
398 \text { firms } \\
\text { in Korea. }\end{array}$ & Shin, 2015 \\
\hline $\begin{array}{l}\text { Acquisition intention of } \\
\text { big data analytics }\end{array}$ & $\begin{array}{l}\text { Degree of data consistency; } \\
\text { Degree of data completeness; } \\
\text { Perceived benefits of external } \\
\text { data usage; Perceived benefits } \\
\text { of internal data usage; Resource } \\
\text { Facilitating condition }\end{array}$ & $\begin{array}{l}\text { Partial least } \\
\text { square }\end{array}$ & $\begin{array}{l}\text { Survey of } \\
306 \text { firms } \\
\text { in Korea }\end{array}$ & Kwon et al., (2014). \\
\hline Behavior intention & $\begin{array}{l}\text { Organization innovativeness, } \\
\text { organization slank; IS infra } \\
\text { maturity; perceived benefits of } \\
\text { big data system; Perceived } \\
\text { usefulness; Perceived ease of } \\
\text { use }\end{array}$ & Conceptual & $\begin{array}{l}\text { Conceptual } \\
\text { model }\end{array}$ & Kim et al., (2013) \\
\hline $\begin{array}{l}\text { Intention to adopt big } \\
\text { data and actual } \\
\text { adoption of big data }\end{array}$ & $\begin{array}{l}\text { Big data dimensions; Perceived } \\
\text { usefulness; Perceived ease of } \\
\text { use; Compatibility; Self- } \\
\text { efficacy; Facilitating } \\
\text { conditions; Perceived benefits; } \\
\text { Perceived costs; Subjective } \\
\text { norms }\end{array}$ & $\begin{array}{l}\text { Partial least } \\
\text { square }\end{array}$ & $\begin{array}{l}\text { Survey of } \\
53 \text { firms in } \\
\text { Spain }\end{array}$ & $\begin{array}{c}\text { Esteves and Curto } \\
\text { (2013) }\end{array}$ \\
\hline $\begin{array}{l}\text { Adoption and } \\
\text { assimilation }\end{array}$ & $\begin{array}{l}\text { Perceived direct benefit; } \\
\text { perceived indirect benefit; } \\
\text { perceived financial readiness; } \\
\text { perceived IS competence; } \\
\text { Perceived industry pressure; } \\
\text { perceived government pressure }\end{array}$ & $\begin{array}{l}\text { Partial least } \\
\text { square }\end{array}$ & $\begin{array}{l}\text { Case-based } \\
\text { and survey } \\
\text { based } \\
\text { study of } 58 \\
\text { firms in } \\
\text { Korea }\end{array}$ & Nam et al., (2015) \\
\hline $\begin{array}{l}\text { Organizational } \\
\text { intention to adopt big } \\
\text { data solutions }\end{array}$ & $\begin{array}{l}\text { Perceived complexity; } \\
\text { perceived compatibility; top } \\
\text { management support; } \\
\text { information security culture; } \\
\text { organizational learning culture; } \\
\text { security/privacy regulatory } \\
\text { concerns, risks in outsourcing }\end{array}$ & Conceptual & $\begin{array}{l}\text { Conceptual } \\
\text { model }\end{array}$ & Salleh et al., (2014) \\
\hline
\end{tabular}


The literature review has been grouped under the variables (both independent and dependent) considered for this research study. The dependent variable has been identified as "Intention to adopt big data services by manufacturing firms". The various independent variables (factors influencing dependent variable) have been identified as:

- Perceived benefits of big data services in terms of cost reduction, increased revenue and better decision making;

- Perceived costs of big data services includes the risk and vulnerability;

- Absorptive capacity implies the skills and domain knowledge for assimilating, managing and leveraging big data and;

- Big data quality indicates the characteristics of big data.

\subsection{RESEARCH METHODOLOGY}

After the extensive literature survey, the research methodology has been centered on the already identified existing core variables. Hence a simple direct relationship of these core variables has been used to create the research model to understand which of them is the most dominant. To further quantify, a detailed structured questionnaire was used to gather the primary data from the various manufacturing firms, based in India. The collected sample size was 205 from survey method. Finally, data collected from the final survey was analyzed. For statistical analysis, a structural model based tool called SmartPLS was used to build, run and validate the process model. Partial Least Square (PLS) regression techniques were used to analyze the latent constructs. SmartPLS unveils both the measurement model (outer model) and the structural model (inner model).

\subsection{RESEARCH FRAMEWORK AND HYPOTHESES DEFINITION}

Fig. 1 is the research framework on which this research study is built upon. Big data services (dependent variable) has attracted the attention of scholars from every field including, finance, business, genomics, neuroscience and economics (Fan et al., 2014). Big data is one of the fastest evolving fields due to convergence of Internet of Things (IoT), cloud computing, and smart assets (Bughin et al., 2010). Manyika et al. (2011) have argued that big data is the next frontier for innovation that may provide competitive advantage to organizations. In this research paper Dijcks (2013) definition of big data is adapted. He defined big data as traditional enterprise data, machine generated, or data stemming from weblogs, sensors, and logs and social data. Since there is huge information generated from this data, this raises challenges for organizations with regard to data storage, analysis and processing, and value, as well as security, privacy and ownership concerns. Gandomi and Haider (2015) characterized big data by : 
JISTEM - Journal of Information Systems and Technology Management

Vol. 14, No. 1, Jan/Apr., 2017 pp. 39-68

ISSN online: $1807-1775$

DOI: $10.4301 / \mathrm{S} 1807-17752017000100003$

(i) Volume: denote the large amount of data that need to be stored or the large number of records;

(ii) Velocity: denote the frequency or speed by which data is generated and delivered; and

(iii) Variety: illustrates the different sources by which data is generated, either in a structured or unstructured format.

(iv) Veracity: White [15] has added the fourth dimension, veracity, to highlight the importance of quality data and the level of trust in a data source.

Besides the four characteristics, scholars (e.g., Forrester (2012)) have also added another dimension, value, to denote the economic benefits from the data. This research study echo the views of Wamba et al.(2015) as well as McAfee et al. (2012) and focus on the four main dimensions of BD. This is because these characteristics affect decision-making behaviors as spurious correlation or incidental endogeneity may lead to wrong conclusions, and also create critical challenges. Boyd and Crawford (2012) have argued that big data is a cultural, technological, and scholarly phenomenon that revolves around technology, analysis, and mythology.

According to Mark and Laney (2012), big data is defined as high-volume, high-velocity, and high-variety information assets that demand cost-effective, innovative forms of information for enhanced insight and decision making. McGahan (2013) further argues that big data is too large to handle with conventional software programs such as Excel, and thus requires specialized analytics. Sun et al. (2015) have argued that big data is data whose sources are heterogeneous and autonomous; whose dimensions are diverse; whose size is beyond the capacity of conventional processes or tools to effectively and affordably capture, store, manage, analyze, and exploit; and whose relationships are complex, dynamic, and evolving. Gandomi and Haider (2015) have attempted to further our understanding of BD and of its potential applications. While the majority of the literature is focused more on BD technology and predictive analytics, Gandomi and Haider (2015) have attempted to provide detailed explanations for volume, variety, velocity, veracity, and value. In the same work, they have outlined various techniques and tools that can enhance decision-making abilities that were limited during the traditional data era (i.e., text analytics, audio analytics, video analytics, social media analytics, and predictive analytics). Some scholars may focus on the variety dimension (Davenport, 2012b) while others emphasize the importance of storage and analysis (Jacobs, 2009; Manyika et al., 2011) highlighting the role of analytics.

The following steps are recommended regarding the adoption of big data by firms (a) Diverse data sets should be brought together by government and firms to manage the quality of data collection and data capture across the board (Shin, 2015); (b) Data availability, free flow of data across the network and data sharing by various applications and systems should be favored by firms (Kwon et al., 2014); (c) IT capability of maintaining consistency in corporate data elements should be provided by firms to encourage usage of available data (Kwon et al., 2014); (d) Firms should promote the experience of utilizing their data and infrastructure (i.e., to manage 
the company's digital data and analysis experience) becomes IT capability that can be mustered for competitive advantages (Kwon et al., 2014 and Shin, 2015); (e) Strict data security practices must be adhered to and maintained in line with sensitive data by firms (Shin, 2015); (f) Firms should enhance the policy concerning privacy protection of users by addressing the purpose rather than prescribing the mechanism.

The discussion of the independent variables follows:

\subsubsection{DATA QUALITY}

In order to provide an appropriate foundation for analysis, a sufficiently comprehensive set of data quality factors is needed. DeLone and McLean (2003) argued that only high quality data are fit for their intended uses in operations, decision making and planning. Data quality is often regarded as the degree to which the data fits its use. Shin (2014) defined data quality as the fitness for use of information, determined by whether or not the data meets the requirements of its authors, users and administrators. Big data is less a matter of data volume than the quality of data to improve quality and efficiency in the delivery of services (Kwon et al., 2014; Tinati et al, 2014). The four core point of the big data quality are (Gandomi and Haider, 2015) 1. Structured and Unstructured data sets can be used based on the different user requirements and same data sets can be reused for different outcome. 2. When data is migrating from one source application to different target application, data can be recognized as error or inconsistent with target application. 3. Historical data lifetime can be extended by applying validation and with data governance. 4 . The authenticity of the information and the level of trust in a data source.

The importance of data quality in both decision-making and operational processes has also been emphasized by numerous studies (Dubey et al., 2015; Shin, 2015; Chen et al., 2014; Cheong and Park, 2005). The high data quality are identified by its accuracy, precision, timeliness, currency and completeness (Chen and Zhang, 2014). The quality aspect of data is considered by organizations to have relative importance, which is reflected by the amount of investment or policies targeted at its maintenance or improvement. In the business arena, it has been rationalized high quality data is a valuable asset, increasing customer satisfaction, improving revenues and profits, and offering a strategic competitive advantage (Shin, 2013; Gandomi and Haider, 2015). Therefore, the following hypothesis is formulated from the above discussion:

Hypothesis 1 (H1). Big Data quality has a positive effect on the manufacturing firms' adoption of big data services.

Hypothesis $2(\mathrm{H} 2)$. Big Data quality has a positive effect in terms of perceived benefits of big data services for manufacturing firms.

Hypothesis 3 (H3). Big Data quality has a positive effect in terms of perceived costs of big data services for manufacturing firms. 
JISTEM - Journal of Information Systems and Technology Management

Vol. 14, No. 1, Jan/Apr., 2017 pp. 39-68

ISSN online: $1807-1775$

DOI: $10.4301 / \mathrm{S} 1807-17752017000100003$

Hypothesis 4 (H4). Big Data quality has a positive effect on absorptive capacity of big data services for manufacturing firms.

\subsubsection{PERCEIVED BENEFITS OF BIG DATA SERVICES}

Perceived benefits are advantageous results that enhance self-efficacy or provide values by making it easier to achieve superordinate goals or values (Gutman, 1982). Rogers (1983) found that perceived benefits had a positive relationship to the adoption of technology. Similarly, Kendall et al. (2001), Tan \& Teo (2000), Thong (1999), and Moore \& Benbasat (1991) found that perceived benefits was the best predictor of the adoption of innovations. In an organizations adoption decision, perceptions of favorable benefits from an innovation provide economic and political legitimacy to the adoption decision (Clemons 1991). The degree of perceived benefit is often expressed in terms of economic profitability, savings in time and effort, and cost reduction.

Perceived benefits come from productivity enhancement, quality improvement, cost reduction, gain in market share, new market development and intrinsic and extrinsic rewards (Calantone et al., 1998; Davis et al., 1989; Lefebvre et al., 1995). Initial research by Wixom \& Watson (2001) indicates that big data services can offer several benefits to an organisation that include enabling effective decision support and business applications (e.g. CRM, SCM), facilitating data analytics, ensuring data integrity, accuracy, security, and availability; easing the setting and enforcing of standards, facilitating data sharing, and delivering the right information to the right person during the right time (Back 2002; Goodhue, Quillard \& Rockart 1988; Goodhue, Wyboa \& Kirsch 1992; Wixom \& Watson 2001).

The experience of utilizing a company's data and infrastructure (i.e., to manage the company's digital data and analysis experience) becomes IT capability that can be mustered for competitive advantages (Bhatt and Grover,2005). A positive experience with prior IT projects can strengthen a firm's intention to use other information technology. Extending the logic, a close relationship can be projected between the rewarding experience of data usage and adoption intention of big data services. Past successful experience with data usage may become a proxy for big data usage in lessening uncertainties about the new endeavor. Thus, positive benefits accrued from the usage of big data are expected to boost a firm's expectation of benefits that the big data service-driven business operation and decision making affords and thus motivation to capitalize the innovation. Big data services are in general geared toward the processing of heterogeneous and informal data from external sources (e.g., data from social media etc.), while conventional business intelligence technologies mainly utilize formal and internal source data (e.g. performance index, ERP database etc.). In this light, companies with positive benefit experience through data usage may be more inclined to try big data services. In other words, if a company has a successful history of developing competence for processing data and of benefiting from its usage experience, this history may work as an instigator of big data analytics. Thus, we posit the following hypotheses. 
JISTEM - Journal of Information Systems and Technology Management

Vol. 14, No. 1, Jan/Apr., 2017 pp. 39-68

ISSN online: $1807-1775$

DOI: $10.4301 / \mathrm{S} 1807-17752017000100003$

Hypothesis 5 (H5). The perceived benefits of big data services is positively related to the manufacturing firms' adoption of big data services.

\subsubsection{PERCEIVED COSTS OF BIG DATA SERVICES}

Perceived costs has been organizational readiness aspect that needed to be incurred in the adoption of an innovation (Iacovou et al., 1995). Financial investments and administrative costs have been two main sources of perceived costs (Chau and Hui, 2001). Financial investments dealt with the setup costs, operating costs, and training costs related to the adoption (Iacovou et al., 1995, p. 469). The other source of costs incurred in the adoption process has been related to the potential implementation and administrative costs. According to Swanson (1994), some IT impacted not only the technical core of the organization but also the administrative core of the host firm business. Perceived higher cost would led to lower the intention of adoption (Sharma, 2007). Big data services have been offering new opportunities and capabilities to organizations, but equally creating challenges for stakeholders (Kaisler et al., 2013; Lohr, 2012). The perception of high initial investment costs and operation costs for big data services could hinder its adoption. Costs associated with big data services implementation included cost of hardware, software and time and costs required for setup, running and training. It also includes the security and privacy of data.

Hypothesis 6 (H6). The perceived costs of big data services is negatively related to the manufacturing firms' adoption of big data services.

Hypothesis 7 (H7). The perceived costs of big data services has a negative effect on the perceived benefits of big data services for manufacturing firms.

\subsubsection{ORGANIZATIONAL ABSORPTIVE CAPACITY}

Absorptive capacity is the ability of organizational employees to utilize preexisting or available knowledge (Griffith et al., 2003). According to Alavi and Leidner (2001), absorptive capacity facilitates a sort of recreation process of the knowledge within organization member's minds. An organization's absorptive capacity also indicates its ability to recognize the value of new internal and external information, assimilate and apply it effectively to realize economic benefits (Cohen and Levinthal, 1990). Sambamurthy and Zmud (1999) found it critical factor for an organization's innovativeness. In the IT domain, an organization's absorptive capacity reflects organization's capability to absorb information relating to suitable IT innovations through its employees' knowledge repositories, cognitive structures and processes for supporting strategic or operational activities and enhancing organizational performance (Boynton et al., 1994). According to many research on new product development and management, absorptive capacity is a prerequisite for rapid innovation and flexible organizational response to changing market conditions (Nonaka, 1991). A major IT innovation like big data services requires an awareness of 
what it can provide or enable, and an understanding of exploiting its potential within an organizational context or need (Kwon et al., 2014). Adoption of big data services is unlikely unless key stakeholders and users can creatively identify unique ways through which new knowledge can be extracted by integrating structured and unstructured data from multiple functional areas within and outside the firm (Chen et al., 2012). However, without the existence of adequate knowledge such creative thinking may be improbable within the firm. In a study by Fichman (1992) it was found that the ability to adopt is critical with respect to Type II innovations; such ability has been found to be a key in adoption of data warehouse (Ramamurthy et al., 2008), EDI (Kuan and Chau, 2001), open systems (Chau and Tam, 1997). Fully leveraging the capabilities of the big data services requires not only the necessary IT resources, but also the experts with domain knowledge and ability for interpreting the results for identifying growth opportunities and acting on new insight. In light of the above arguments, following hypotheses are propose:

Hypothesis 8 (H8). Absorptive capacity has a positive effect on the manufacturing firms' adoption intention of big data services.

Hypothesis 9 (H9). Absorptive capacity has a positive effect in terms of perceived benefits of big data services for manufacturing firms.

Hypothesis 5 (H5). Absorptive capacity has a negative effect in terms of perceived costs of big data services for manufacturing firms.

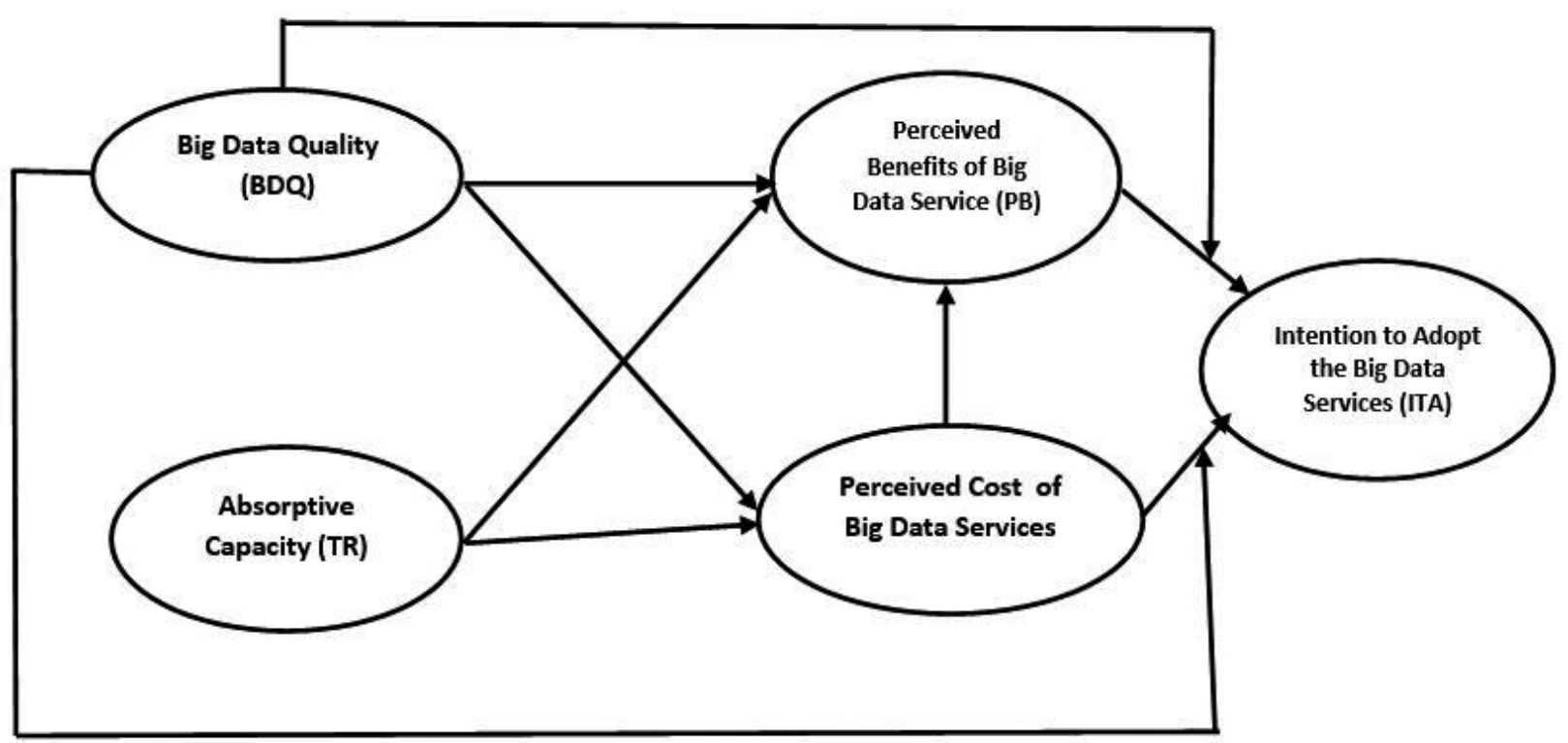

Figure 1. Proposed research framework. 


\section{METHODS}

The secondary data had been obtained from the literature survey, resulting in four core variables. A detailed discussion has already been captured in the literature survey section earlier. Subsequently, a structured questionnaire was used to collect the primary data from 205 respondents.

\subsection{DATA COLLECTION}

A pilot survey, using personal interviews with 30 respondents, was conducted to obtain holistic feedback about manufacturing firm's adoption of big data services. This pilot survey was developed by framing relevant questions under each of the core variables identified from the literature survey. The survey included both qualitative and quantitative questions for latent constructs. Based on the feedback, the final survey questionnaire was formulated. This final survey was administered only to those manufacturing firms that were well aware of the big data services. A note at the beginning of the questionnaire explained the purpose of this research and stated that the confidentiality of the data would be maintained. The questionnaire was divided into two parts:

- The first part of the survey captured the demographic details of the respondents (Table 2).

- The second part of the survey captured influence, usage and adoption of big data services, assuming that the respondents do have the necessary awareness and acceptance of the big data (Table 3).

For each latent construct, three to seven questions (indicators) were formulated capturing the adoption by manufacturing firms. All the reflective indicators were measured on a 5-point Likert scale using scales from "Strongly Disagree" to "Strongly Agree". The data were collected through online survey (via Google Docs). This final survey questionnaire was sent to about 900 participants located in various cities of India. Out of 900 requests, a total of about 221 responded back positively. After editing, only 205 responses were found useful. The response rate was about $23 \%$ and the participants were recruited from the manufacturing firms in India. This survey was administered to them through email requests. Finally, there were 205 complete and usable responses. Table 2 summarizes the demographic characteristics of the respondents. The respondents for this research are manufacturing firms in emerging economies like India. The responses were compared based on demographic variables, including employees' strength, annual sales, IT investment, company age, role in organization and big data adoption status to evaluate the response bias. For the 205 respondents, the demographics characteristics are described as per Table 2 given below. 
JISTEM - Journal of Information Systems and Technology Management

Vol. 14, No. 1, Jan/Apr., 2017 pp. 39-68

ISSN online: $1807-1775$

DOI: $10.4301 / \mathrm{S} 1807-17752017000100003$

Table 2. Summary of respondent's profile.

\begin{tabular}{|l|c|c|}
\hline Variables & Frequency & Percentage (\%) \\
\hline Number of employees & & \\
\hline$<=200$ & 25 & $12.3 \%$ \\
\hline $201-400$ & 75 & $36.8 \%$ \\
\hline $400-800$ & 57 & $28.2 \%$ \\
\hline$>800$ & 48 & $22.7 \%$ \\
\hline Role in organization & 31 & $15.2 \%$ \\
\hline CEO/COO/CIO/CFO & 52 & $25.6 \%$ \\
\hline V.P., General Manager, etc. & 63 & $31 \%$ \\
\hline Director, Controller, etc. & 59 & $28.2 \%$ \\
\hline Manager, Senior Analyst, etc. & & \\
\hline Age of the responding firms (years) & 30 & $28.5 \%$ \\
\hline 1-10 & 58 & $56.3 \%$ \\
\hline 11-20 & 117 & \\
\hline$>$ 20 & & $17 \%$ \\
\hline Annual Revenue (turnover) & 34 & $28.5 \%$ \\
\hline Less than USD 40000 & 58 & $19.5 \%$ \\
\hline USD 40000- USD 1 million & 40 & $35 \%$ \\
\hline USD 1 million- USD 4 Million & 73 & \\
\hline More than USD 4million & & \\
\hline
\end{tabular}

\section{STATISTICAL TECHNIQUES/TOOLS FOR DATA ANALYSIS}

Structural Equation(s) Modeling (SEM) is a statistical technique for simultaneously testing and estimating causal relationships among multiple independent and dependent constructs. Exploratory Factor Analysis (EFA) using SmartPLS has been used for the initial set of 30 respondents. EFA was used to uncover the underlying structure of the four core variables. The assumption was that any independent factor could be more associated. There is no prior theory in EFA. Later, for 205 respondents, Confirmatory Factor Analysis (CFA) has been used.

\subsection{DATA ANALYSIS}

Partial Least Square (PLS) technique has been used to validate the measurements and to test hypotheses using SmartPLS 2.0 M3 software (Ringle et al., 2005). The PLS technique employs a component-based approach for model estimation and is best suited for testing complex structural models. The PLS technique was selected because it does not impose any normality requirements on the data. A two-step approach has been used to first assess the quality 
of measures (as per this research study) using the measurement model (outer model), and then to test the hypotheses using the structural model (inner model) (SEM stage, Joreskog \& Sorbom, 1993) as recommended by Segars and Grover (1993). SmartPLS 2.0 M3 software http://smartpls.com (Ringle et al., 2005) is used for path modeling with latent variables. The tool is used to measure the validity and reliability of the constructs. Besides PLS Algorithm, Bootstrapping is used with 205 cases (sample size) and 170 samples (resamples) to generate the standard error of the estimate and t-values. SmartPLS uses the PLS technique to simultaneously examine theory and measures (Hulland, 1999).

\section{DISCUSSION, ANALYSIS AND FINDINGS}

An important conclusion of this research is that perceived costs of big data services and absorptive capacity are not the most important factor for manufacturing firms to adopt big data services. Perceived benefits of big data services and big data quality are considered to be the top two priorities for them to adopt big data services, followed by perceived costs and absorptive capacity of big data services This indicates that manufacturing firms are happy to adopt big data services due to the benefits they provide and the quality of data the firms have. A confirmatory factor analysis (CFA) has been conducted to assess reliability, convergent validity and discriminant validity of the scales, as given below:

\subsection{MEASUREMENT VALIDATION AND RELIABILITY}

The reliability of these research measurements has been evaluated using Cronbach's alpha and composite reliability scores. The constructs are considered adequate when the Cronbach's alpha scores are above the minimum recommended value of 0.6 (Hair et al., 2010; Malhotra, 2010; Robinson et al, 1991) and composite reliability scores are above the recommended cut-off of 0.7 (Gefen et al., 2000). Composite reliability is considered a more rigorous estimate for reliability (Chin \& Gopal, 1995). As shown in Table 3, the composite reliability scores exceed 0.8 and Cronbach's alpha values exceed 0.7 . Thus the model can be considered as reliable. 
JISTEM - Journal of Information Systems and Technology Management

Vol. 14, No. 1, Jan/Apr., 2017 pp. 39-68

ISSN online: $1807-1775$

DOI: $10.4301 / \mathrm{S} 1807-17752017000100003$

Table 3. Reliability Validation for Latent Constructs.

\begin{tabular}{|l|c|c|c|c|c|}
\hline Overview & AVE & $\begin{array}{c}\text { Composite } \\
\text { reliability }\end{array}$ & $\begin{array}{c}\text { Cronbach } \\
\text { S alpha }\end{array}$ & R square & $\begin{array}{c}\text { LV index } \\
\text { values }\end{array}$ \\
\hline Big Data quality & 0.501 & 0.831 & 0.745 & 0.000 & 3.882 \\
\hline Absorptive Capacity & 0.689 & 0.869 & 0.774 & 0.129 & 3.465 \\
\hline $\begin{array}{l}\text { Perceived benefits of } \\
\text { big data services }\end{array}$ & 0.503 & 0.855 & 0.796 & 0.409 & 4.070 \\
\hline $\begin{array}{l}\text { Perceived costs of big } \\
\text { data services }\end{array}$ & 0.832 & 0.952 & 0.933 & 0.251 & 3.654 \\
\hline $\begin{array}{l}\text { Adoption of big data } \\
\text { services }\end{array}$ & 0.862 & 0.926 & 0.839 & 0.582 & 4.291 \\
\hline
\end{tabular}

\subsection{CONVERGENNT VALIDITY}

For testing the convergent validity, each item's loading on its underlying construct should be above 0.70 (Chin et al., 2003). Also, the average variance extracted (AVE) for each construct should be above the minimum recommended value of 0.50 (Bagozzi \& Yi, 1988; Dillon \& Goldstein, 1984; Fornell \& Larcker,1981). As observed in Table 3, the AVE values are above 0.501. Also, each item's loading constructs are above 0.7, as shown in Table 4. These two tests prove the convergent validity is satisfactory for the measurement model. Also, as shown in Table 4 the item-to-construct correlation vs. correlations with other constructs, shows that the indicators are the part of the highlighted constructs only and are not part of other constructs. 
JISTEM - Journal of Information Systems and Technology Management

Vol. 14, No. 1, Jan/Apr., 2017 pp. 39-68

ISSN online: $1807-1775$

DOI: $10.4301 / \mathrm{S} 1807-17752017000100003$

Table 4. Item loading for indicators of latent constructs

\begin{tabular}{|c|c|c|c|c|c|}
\hline Construct & Loadings & Ave & $\begin{array}{l}\text { Composite } \\
\text { reliability }\end{array}$ & $\begin{array}{l}\text { Cronbach's } \\
\text { alpha }\end{array}$ & $\begin{array}{c}\mathbf{R} \\
\text { square }\end{array}$ \\
\hline Data Quality & & 0.501 & 0.831 & 0.745 & 0.000 \\
\hline Rapidly increasing size of data & 0.8264 & & & & \\
\hline Getting data timely. & 0.6119 & & & & \\
\hline Access to unstructured data & 0.6849 & & & & \\
\hline Diversity in data. & 0.7188 & & & & \\
\hline Implications from social media & 0.663 & & & & \\
\hline Truthfulness in text data & 0.8264 & & & & \\
\hline Absorptive Capacity & & 0.689 & 0.869 & 0.774 & 0.129 \\
\hline $\begin{array}{l}\text { Data scientists with the domain } \\
\text { knowledge }\end{array}$ & 0.7326 & & & & \\
\hline Skills in handling large data sets. & 0.8801 & & & & \\
\hline $\begin{array}{l}\text { Analysts for interpretation of } \\
\text { information. }\end{array}$ & 0.8659 & & & & \\
\hline Perceived benefits of big data & & 0.503 & 0.855 & 0.796 & 0.409 \\
\hline $\begin{array}{l}\text { Better understanding of the } \\
\text { nature of customers' demands. }\end{array}$ & 0.7692 & & & & \\
\hline Prevent fraudulent events. & 0.7895 & & & & \\
\hline $\begin{array}{l}\text { Developing strategies from } \\
\text { social media data. }\end{array}$ & 0.7423 & & & & \\
\hline Monitor markets in real time. & 0.6809 & & & & \\
\hline Dynamic pricing of products. & 0.4262 & & & & \\
\hline Reduce maintenance costs. & 0.7782 & & & & \\
\hline Perceived costs of big data & & 0.832 & 0.952 & 0.933 & 0.251 \\
\hline $\begin{array}{l}\text { Data sharing threatens business } \\
\text { competitiveness. }\end{array}$ & 0.9146 & & & & \\
\hline Vulnerability of sensitive data. & 0.9219 & & & & \\
\hline High initial investment costs. & 0.8943 & & & & \\
\hline High operational costs. & 0.9178 & & & & \\
\hline Adoption of big data & & 0.862 & 0.926 & 0.839 & 0.582 \\
\hline Use BDA in next few years. & 0.923 & & & & \\
\hline Already using big data services. & 0.9336 & & & & \\
\hline
\end{tabular}




\subsection{DISCRIMINANT VALIDITY}

Discriminant validity was investigated to indicate the extent to which the measures in the model are different from other measures in the same model. In the PLS context, the criterion for discriminant validity is that a construct should share more variance with its measures than it shares with other constructs in the given model (Hulland, 1999). The discriminant validity was examined by testing the correlations between the measures of potentially overlapping constructs and must be different from unity (Anderson \& Gerbing,1988). Also, as shown in Table 4, the correlation between any two constructs is greater than 0.7 . The highest correlation between any two constructs should have a minimum recommended value of 0.60 . Next, as shown in Table 5, the square root of the AVE of each construct is larger than all the cross-correlations between the construct and other constructs (Fornell \& Larcker, 1981). These tests suggest that discriminant validity is satisfactory for the measurement model.

Table 5. Reliability and inter-construct correlations for reflective scales.

\begin{tabular}{|l|c|c|c|c|c|}
\hline $\begin{array}{l}\text { LV } \\
\text { construct }\end{array}$ & $\begin{array}{c}\text { Big data } \\
\text { quality }\end{array}$ & $\begin{array}{c}\text { Adoption } \\
\text { of big data }\end{array}$ & $\begin{array}{c}\text { Perceived benefits } \\
\text { of big data }\end{array}$ & $\begin{array}{c}\text { Perceived costs } \\
\text { of big data }\end{array}$ & $\begin{array}{c}\text { Absorptive } \\
\text { Capacity }\end{array}$ \\
\hline BDQ & 0.707814 & 0 & 0 & 0 & 0 \\
\hline ITA & 0.6778 & 0.92844 & 0 & 0 & 0 \\
\hline PB & 0.6176 & 0.6784 & 0.709225 & 0 & 0 \\
\hline PC & 0.4635 & 0.2228 & 0.2668 & 0.91214 & 0 \\
\hline TR & 0.3603 & 0.1081 & 0.0717 & 0.3429 & 0.83006 \\
\hline
\end{tabular}

Note: Value on the diagonal is the square root of AVE.

\subsection{ASSESSMENT OF THE STRUCTURAL MODEL}

Next, the hypotheses generated out of this research was tested by examining the structural model using SmartPLS software. The structural model includes estimating the path coefficients, which indicates the strength of the relationships between the independent variables and dependent variable and R-square value (variance explained by the independent variables). A bootstrapping re-sampling procedure (Davison \& Hinkley, 1997; Efron \& Tibshirani,1993) of 170 samples was used to determine the significance level of the paths defined within the structural model (Chatelin et al., 2002; Chin \& Gopal, 1995). Bootstrapping results in a larger sample which is claimed to model the unknown population (Henderson, 2005). The corresponding t-values show the level of significance using the magnitude of the standardized parameter estimates between the constructs. A 5\% significance level $(\mathrm{p}<0.05)$ is used as a statistical decision criterion (Fisher, 1925; Cowles \&Davis, 1982). The results of the structural model are summarized in Table 6. 
Out of the ten hypotheses, seven are supported. The variance explained ranges from 0.13 to 0.58.As observed, Hypothesis $\mathrm{H} 1$ is supported because the path from big data quality and intention to adopt big data services is significant $(b=0.488, p<0.01)$. Hypothesis $\mathrm{H} 2$ is supported because the path from big data quality and perceived benefits of big data services is significant $(b=0.712, p<0.01)$. These findings are consistent with similar studies reported in the literature (Kwon et al., 2014; Shin, 2015; Shin 2013, Esteves and Curto, 2013; Shin 2014). A firm's ability to sustain adequate quality level of big data is fundamental to capitalize the IT asset as a strategic and operational value source (Chen et al, 2012). Therefore, for gaining a competitive position by a firm, the key role of IT department is to effectively manage the data/information and business processes. When big data is reliable in quality dimensions, decision making at a manufacturing firm can be more data-driven and subsequently it can find greater benefits from big data services usage. Initially, this virtuous cycle may begin with big data quality management and usage of big data services. With growing benefits realized, meanwhile, manufacturing firms decision makers may be gravitated toward adopting the big data services. Hypothesis H3 is supported as the path from big data quality to perceived costs of big data services is found significant ( $b=0.414$, $\mathrm{p}<0.01$ ) and the hypothesis $\mathrm{H} 4$ is also supported because the path from the big data services to absorptive capacity is also significant $(\mathrm{b}=0.343, \mathrm{p}<0.01)$. According to Rai et al. (2006) managerial capability of a firm's data constitutes its core IT capability. Such big data management capacity is believed to strengthen another resources and application system capacity of firms (Chen et al., 2012). Adoption of big data services not only require large upfront investments in infrastructure, technology, and manpower, but also significant outlays for high quality of big data (Hazen et al., 2014; Kwon et al., 2014), particularly if an organization seeks to fully exploit big data services capabilities throughout the organization and for its strategic advantage (Beath et al., 2012; Mayer-Schönberger and Cukier, 2013; Galbraith, 2014).

Table 6. Summary of hypotheses tests (Path coefficients and hypotheses testing).

\begin{tabular}{|l|c|c|c|c|c|}
\hline $\begin{array}{l}\text { Significant } \\
\text { values }\end{array}$ & $\begin{array}{c}\mathrm{P}<0.1 \\
\mathrm{P}<0.05 \\
\mathrm{P}<0.01\end{array}$ & $\begin{array}{c}1.652 \\
1.971 \\
2.599\end{array}$ & \\
\hline $\begin{array}{l}\text { Hypothesis } \\
\text { No. }\end{array}$ & $\begin{array}{c}\text { Hypothesis } \\
\text { (direction) }\end{array}$ & $\begin{array}{c}\text { Path } \\
\text { coefficient }\end{array}$ & T-value & $\begin{array}{c}\text { Significance } \\
\text { (one-tailed) }\end{array}$ & Supported \\
\hline H1 & BDQ -> ITA & 0.4882 & 4.5371 & P $<0.01$ & Yes \\
\hline H2 & BDQ -> PB & 0.7127 & 7.5829 & P $<0.01$ & Yes \\
\hline H3 & BDQ -> PC & 0.4141 & 3.9013 & P $<0.01$ & Yes \\
\hline H4 & BDQ -> TR & 0.3432 & 2.7351 & P $<0.01$ & Yes \\
\hline H5 & PB -> ITA & 0.41 & 4.0289 & P $<0.01$ & Yes \\
\hline H6 & PC - > ITA & -0.0861 & 1.1889 & n.s & No \\
\hline H7 & PC -> PB & 0.0353 & 0.4675 & n.s & No \\
\hline H8 & TR -> ITA & 0.0801 & 1.2587 & n.s & No \\
\hline H9 & TR -> PB & 0.1998 & 2.0125 & P $<0.01$ & Yes \\
\hline H10 & TR -> PC & -0.1559 & 1.6155 & P $<0.1$ & Yes \\
\hline
\end{tabular}


Big data services are used for both business operations and for enhancing effectiveness in strategic decision making (Woerner and Wixom, 2015; Groves et al., 2014) for day to day operation like demand prediction, understanding current market conditions and customer demands, and new market opportunities. The analysis reveals that successful usage experience of big data through business application systems could prompt the adoption intention of big data services, which might further galvanize a firm's competitive advantage, a chain effect in strengthening IT capability of a firm (McGuire et al., 2012; Prescott, 2014).

Several studies on the adoption of IT innovations had identified perceived benefits and/or perceived costs as important factors associated with technological adoption (Saunders et al., 1992; Mehrtens et al., 2001; Min and Galle, 2003).

In this study it was found that successful harvesting of benefits from big data services were positively associated with the dependent variable, adoption intention of big data services $(\mathrm{H} 5 \mathrm{~b}=0.41, \mathrm{p}<0.01)$. The analysis indicates that benefits from big data could be a positive force, in launching big data services adoption. This implies that rewarding experience of utilizing unstructured and structured data motives to obtain big data services that might be able to improve its IT capability in taking advantage of big data. It becomes an indication that when a firm is ready to make use of big data for strategic decision-making, understanding customers' demand and other business opportunities, possibly facilitate the adoption intention of big data services.

Surprisingly, although the relationship of perceived costs adoption of big data services and with perceived benefits of big data services is in the expected negative direction, the results are not significant (Hypothesis 6 and hypothesis $7: b=-0.086, p>0.1$ ). This finding is consistent with the studies of Teo (2009) and inconsistent with the study of Kuan and Chau (2001). One plausible reason is that although big data services may be costly, it entails much lower costs compared to traditional data analytics tools as most of the big data services are open sources.

Manufacturing firms with rewarding experience in utilizing data for decision making may not be too enthusiastic about such innovations as big data services demands costly investment in its deployment and has a stiff learning curve (Adam, 2009; Juha et al., 2012). For the managers of firms who think that big data services are too expensive to implement, with the cost of data storage and computing devices decreasing, this obstacle is transposed. Interestingly, the lack of relationship of perceived costs with big data services adoption could suggest that firms are generally aware of the benefits of big data services. Specifically, real-time big data services significantly lower costs than traditional business intelligence.

A key finding of this study is the absorptive capacity had significant positive effect on perceived benefits (H9) and negative effect on perceived costs (H10) (Cohen and Levintha, 1990; Fichman, 1992) and yet received little empirical attention, except in one major study (Boynton, 1994). Greater absorptive capacity signals better appreciation of the potential benefits from adopting big data services. Clearly, the adoption of a technology innovation is more than 
investing the financial resources to acquire or build it. The ability to create and nurture an environment to absorb and transfer the skill base to exploit the nuances of an innovation is a key to its adoption. This is especially critical in the context of an IT infrastructure type innovation such as big data services (Chen and Zhang, 2014). While the relationship between absorptive capacity and adoption intention of big data services (H8) is found insignificant in this study which is inconsistent with the work of Ramamurthy et al. (2008). This may be due to prior knowledge and experience of business intelligence and data analytics tools used for decision making. Manufacturing firms may be reluctant to take risks and to adopt big data services not directly related to their current skills and experience (Rogers, 1995; Son \& Han, 2011). The following figures exhibit the findings using PLS structural modeling (Figures. 2-4):

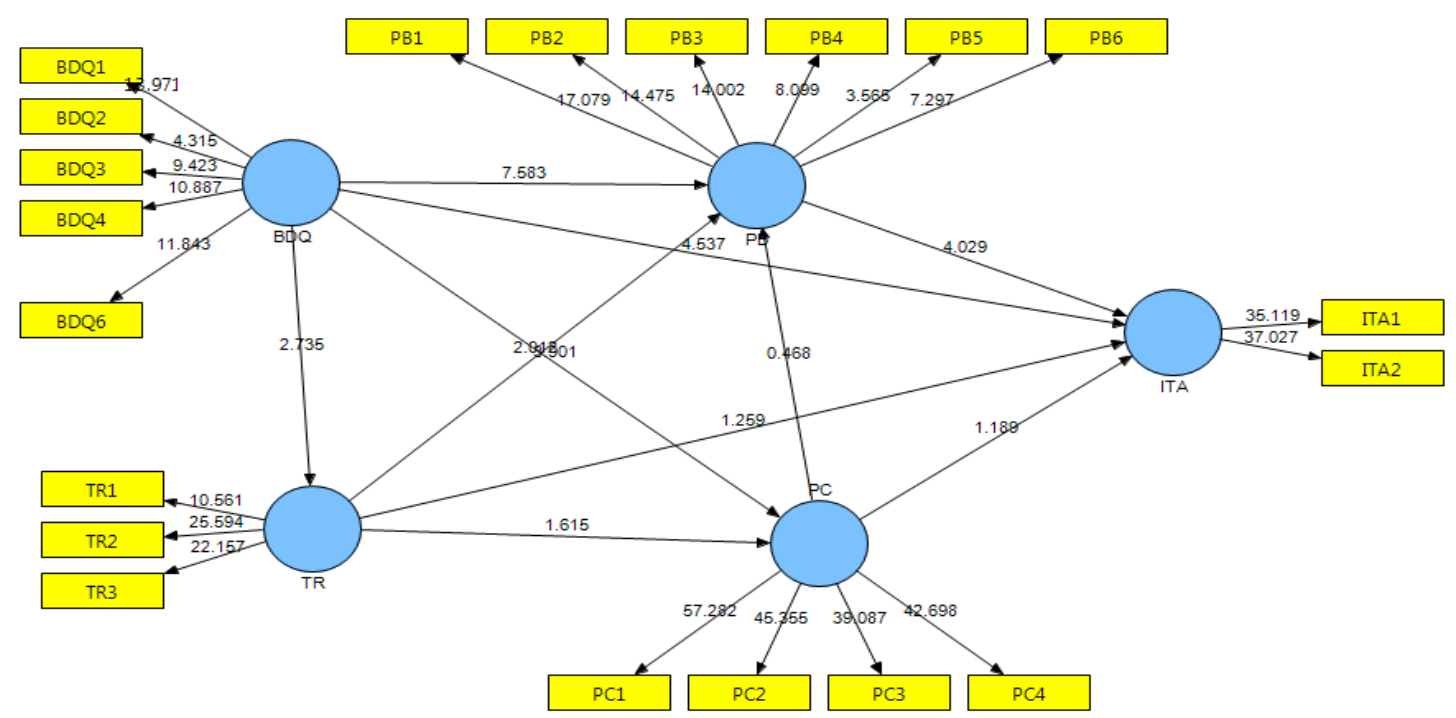

Figure 2. Results of PLS structural model analysis (SmartPLS snapshot). 
JISTEM - Journal of Information Systems and Technology Management

Vol. 14, No. 1, Jan/Apr., 2017 pp. 39-68

ISSN online: $1807-1775$

DOI: $10.4301 / \mathrm{S} 1807-17752017000100003$

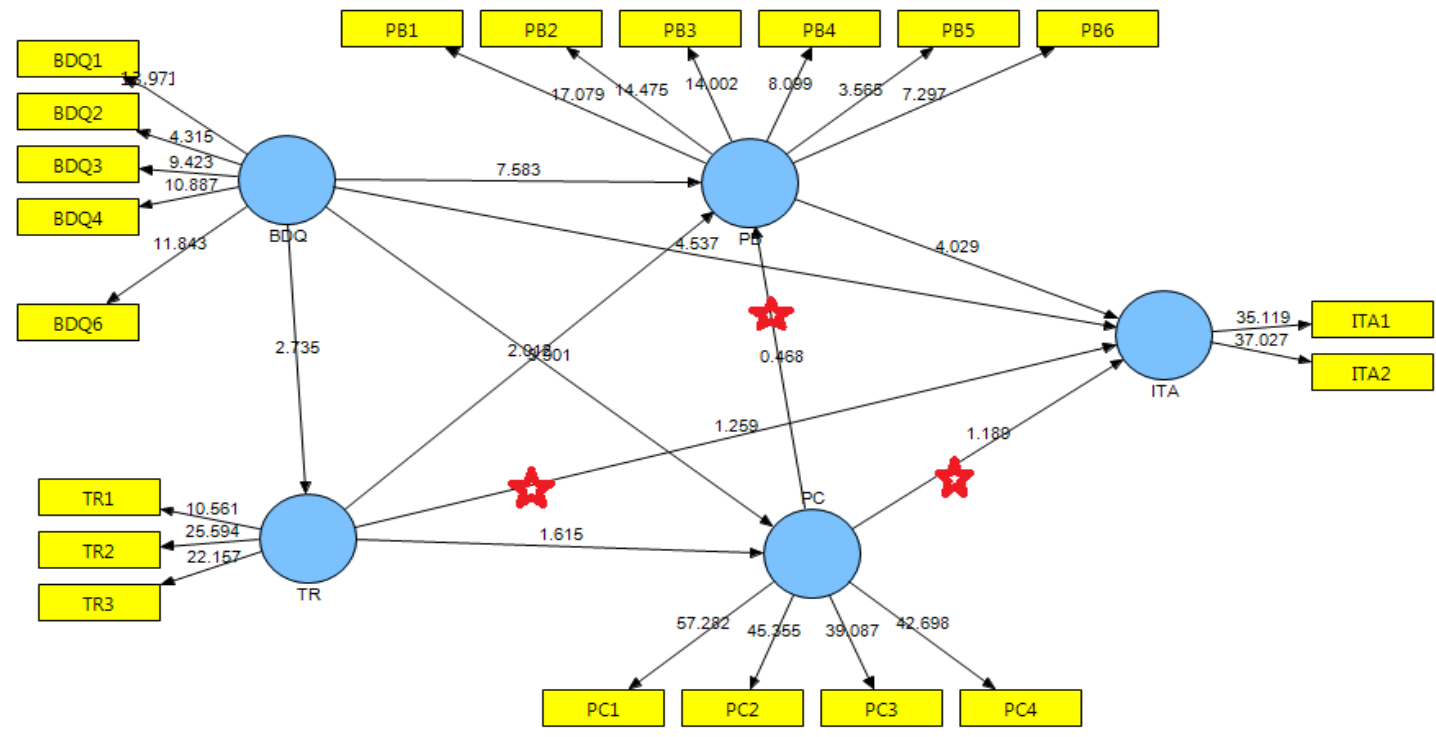

Figure 3. The stars represent those three hypotheses which are not supported.

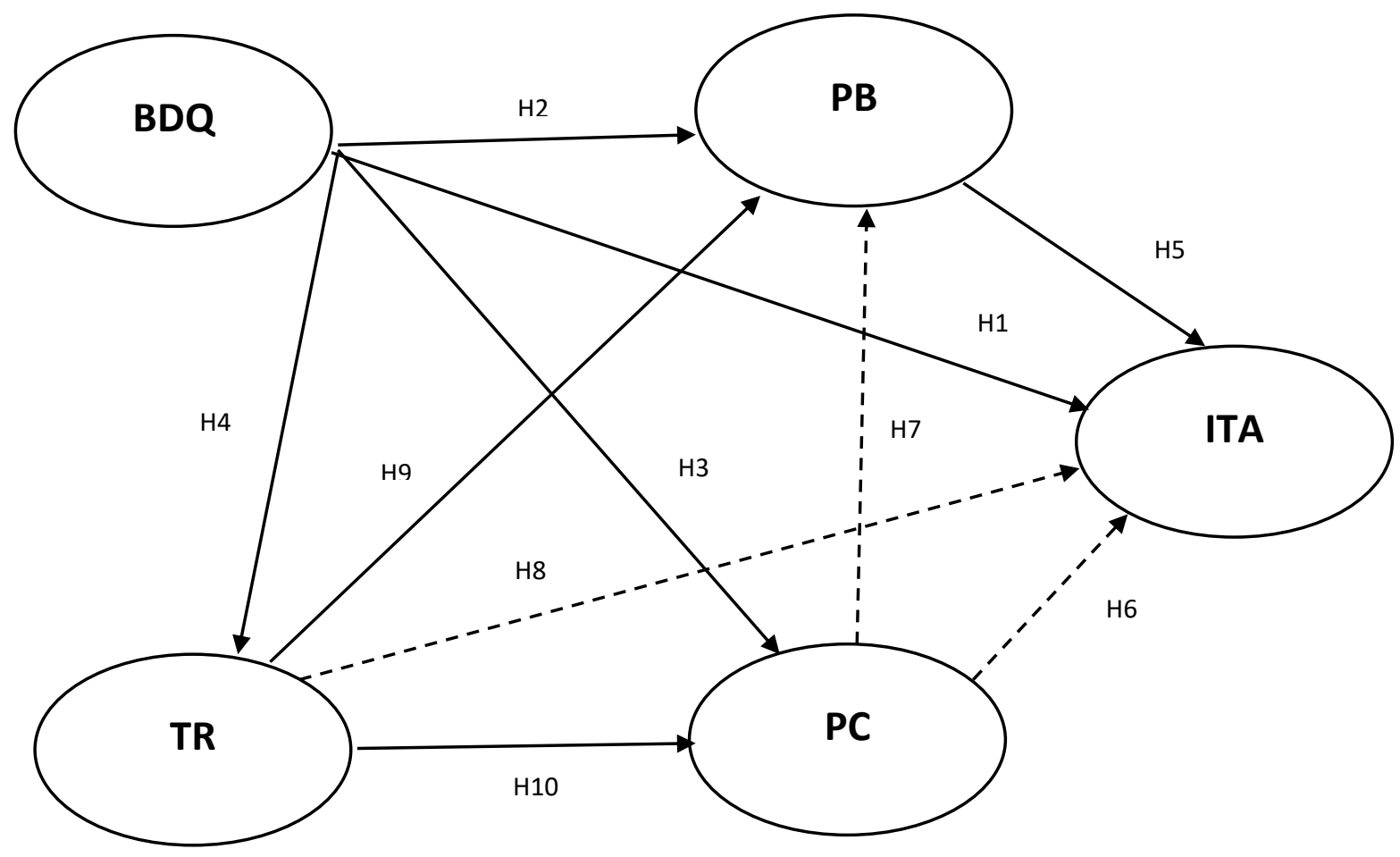

Figure 4. Results of PLS structural model analysis Note: Significant relation $(\rightarrow)$, Insignificant relation( $\rightarrow \rightarrow)$. 


\subsection{ASSESSMENT OF FIT}

The goodness-of-fit (GoF) measure has been conducted for assessment of this research PLS path modeling (Amato et al., 2004). GoF is suggested as a global fit measure for PLS path modeling (Tenenhaus et al., 2005).GoF $(0<\mathrm{GoF}<1)$ is defined as the geometric mean of the average communality/AVE and average $\mathrm{R}^{2}$ (for endogenous constructs).

$$
G o F=\sqrt{\overline{A V E}} * \overline{R^{2}}
$$

Following the guidelines of Wetzels et al. (2009), the GoF value has been calculated, which validates the PLS model of this research study. The GoF value for this research model is 0.43 (geometric mean of average communality/AVE was 0.677 and average of $\mathrm{R}^{2}$ was 0.274 ). The GoF value for the model exceeds the minimum cut-off value of 0.36 for large effect sizes of $\mathrm{R}^{2}$. The GoF value provides adequate support to validate the PLS model (Wetzels et al., 2009). The baseline values for validating the PLS model globally are GoFsmall =0.1, GoFmedium = 0.25 and GoFlarge $=0.36$ (Akter et al., 2011).

\section{IMPLICATIONS FOR THE INDUSTRY}

This study focused on identifying the core variables which influence the adoption of big data services in manufacturing firms. Contrary to the generic belief, absorptive capacity is not the top three factors for manufacturing firms to adopt big data services. However, it is definitely a crucial factor forcing the perception of big data services benefits and costs by firms. The other major finding for this study are that for manufacturing firms, benefits (second major factor) of the big data services is acceptable across business processes. This is a much stronger proposition for firms to move to big data services compared to absorptive capacity. The big data quality scores the topmost slot. This is primarily fuelled by the exponential growth of structured and unstructured data from internet, sensors and more. Meaningful insights are derived for decision making from these data by storing it and analysing it in (near) real time.

The industry players providing big data services should focus on availability of storage and analytical tools to acquire, handle and analyses both internal and external data available to an organization. It is more about providing firms a general solution which can provide more accurate information and insights for decision making in (near) real time. The forthcoming usage and adoption of big data services by firms is very much dependent on how the big data service providers are able to build the trust, faith, confidence and reliability of their big data services for manufacturing firms to positively analysing the actual and real-time data of customers and devices via big data tools. A lot more emphasis is needed on this aspect by the industry players. Using big data services for real time decision making indicate use of storage, computing and 
visualizing tools as well as the availability of IT-savvy developers with the right skillsets to harness the raw power of big data.

Perceived costs has been organizational readiness aspect that needed to be incurred in the adoption of an innovation (Iacovou et al., 1995). Financial investments and administrative costs have been two main sources of perceived costs (Kuan and Chau, 2001). Financial investments dealt with the setup costs, operating costs, and training costs related to the adoption (Iacovou et al., 1995, p. 469). The other source of costs incurred in the adoption process has been related to the potential implementation and administrative costs. According to Swanson (1994), some IT impacted not only the technical core of the organization but also the administrative core of the host firm business. Perceived higher cost would led to lower the intention of adoption (Sharma, 2007). Big data services have been offering new opportunities and capabilities to organizations, but equally creating challenges for stakeholders (Galbraith, 2014; Jin et al., 2015).The perception of high investment in implementation and operation costs for big data services could hinder its adoption. Costs associated with big data services implementation included cost of hardware, software and time and costs required for setup, running and training. It also includes the security and privacy of data.

\section{IMPLICATIONS FOR RESEARCH}

The findings of this research is multi-fold. Firstly, it indicates few variables (perceived benefits, perceived costs and absorptive capacity) which are intuitively in favour of firms using and adopting big data services. Secondly, this research indicates one variables (big data quality) that needs immediate attention by the industry leaders. This is like a catalyst for the big data service providers, which if improved, can result in immediate usage and faster adoption of big data services by firms. This is further supported by the fact that governments and individual data owners are jointly brining diverse data sets together to manage the quality of data collection and data capture across the board. This would improve the quality of big data for industries (Shin, 2015). Thirdly, this research indicate a specific variables (absorptive capacity) which is counterintuitive to the generic understanding prevalent in the market today. Lastly but not the least, this research points to several other new variables which are also prompting manufacturing firms to use and adopt big data services besides the core variables discussed in this paper.

This research proves the various other inter-relationships do exist between the four core variables, which are significant, as explained by various hypotheses above. So even though the primary latent variable relationship with adoption intention of big data services is insignificant but that same latent variables have strong relationship and significance with other latent variables. For example, absorptive capacity for using big data services is positively related to the perceived benefits and negatively related to perceived costs of big data services, even though absorptive capacity is not main factor resulting in adoption intention of big data services, as per this research study. 


\section{LIMITATIONS AND SCOPE FOR FURTHER RESEARCH}

This research has been primarily conducted in India and may not be representative of entire developed and emerging economies. This research is limited to in-depth study of only four (core) latent variables, supported by the existing literature survey. During the survey, other variables and observations are mentioned by manufacturing firms to use and adopt big data services at the present time but they have not been covered in this study. These other factors are, Duration of big data service implementation; Smooth integration of big data services with information and integration with other services should be simpler; Use of latest and most compatible solutions; Data synchronization; Attracting talent - top developers want to work in the big data tools today;

Tools on the big data storage and computing are usually general and therefore, customizing them to suit the organization's needs is a problem (especially true for connecting IoT and big data for streamlining the forecasting systems in manufacturing firms). As for specific requirements of manufacturing firms, customization may not be possible and therefore, difficult to be relied on; (1). Production control system should run unhindered also on big data services as it would run if the production system is totally in control of an informationprocessing organization. (2). Are enough business ready software based packages available for big data for manufacturing firms? Will it improve the supply chain processes and their performance? Does they examine the current supply chain processes using organizational theories? Is there any big data services packages available to improve operations using social media data? How big data services improve the world-class sustainable manufacturing. (3). Are enough integration methods available on the big data services? For example, integrating world class manufacturing practices as just-in-time, total quality management, total productive maintenance, employee involvement and simplicity with big data for decision making, inter alia, innovation, customization of products and services and visibility.

The above details signify that there is tremendous scope of further research in big data services area which includes further investigation into these new variables.

\section{CONCLUSIONS}

Big data services are definitely making waves with service as well as manufacturing firms and is slowly creeping into their business strategy formulation and implementation now and in the near future. Manufacturing firms are not hesitant to incorporate big data services into their business strategy inspite of the few concerns being cited by industry pundits. As per this research study, big data quality is the biggest factor cited by manufacturing firms to adopt big data services. The second major factor to adopt big data service is perceived benefit of big data services. The third factor for the adoption of big data service is the absorptive capacity and the fourth variable is perceived costs of big data. This means that manufacturing firms find the big 
data services adequately beneficial for their business, not costly to adopt and lastly but not the least is that a good quality of data and skill sets to handle the data helps manufacturing firms to bring competitive advantages. This observation is supported by and builds on the arguments of Kwon et al. (2014), Shin (2014, 2015), Hazen (2014), Demirkan and Delen (2013) and Esteves and Curto (2013) stating quality of internal and external data. Regarding benefits of big data services, this observation agrees with Hahn and Packowski (2015), Rozados and Tjahjono (2014), Fairhurst (2014), Varian (2014). Regarding absorptive capacity to manage big data, it is in line with Waller and Fawcett (2014), Bersin 2012, Manyika et al. (2011), Tambe (2014) and Davenport and Dyché (2013). The fourth and last negative factor is perceived costs which indicates the manufacturing firms who perceived big data services costly and difficult do not realise the benefits of big data services and will not go for its adoption. Instead of big data services they prefer decision making through hunches or tradition business intelligence. This is inline with the observations of Whitehouse (2014), Harford (2014), Kaisler et al. (2013), Lohr (2012), Iş1k et al. (2013), Brown et al. (2011) and McAfee and Brynjolfsson (2012). As per Gerhardt et al. (2012), business leaders should engage in development of talents in the entire big data ecosystem to earn more benefits from analysing data. According to Demirkan and Delen (2013), the big data services is not yet a viable option for firms because costs for decisionsupport systems are high.

Few other positive factors cited for using and adopting big data services by manufacturing firms are: Easy to use; cost effective; Scalability of service and faster insights delivery; Crowd sourcing and multiple revenue models; Branding effort to keep up with technology with intangible benefits such as confidence and trust from investors; Big data services is clearly the technology of the future; the faster the firms adapt and accept this the better positioned the firms are; Scalability and reliability; lesser trained employees and hassle free; Secure; Ability of big data services to achieve firms trust and commitment. The actionable items for a manager for adopting big data services is to make the best use of big data available to their firms and big data services as it is being provided by various big data services vendors (both local and global). Especially with manufacturing firms based in India, where data related to customers and devices are easily available, accessing the big data services for strategic decision making should become second nature for these managers. Based on this research we foresee the adoption of big data services to grow exponentially and provide huge befits to manufacturing firms in the days to come. 


\section{REFERENCES}

Akter, S., D’Ambra, J., \& Ray, P. (2011). Trustworthiness in mHealth Information Services: An Assessment of a Hierarchical Model with Mediating and Moderating

Alavi M, D.E. Leidner (2001). Knowledge management and knowledge management systems: conceptual foundations and research issues, MIS Quarterly 25 (1): 107-136.

Amato, S., Esposito Vinzi, V., \& Tenenhaus, M. (2004, March). A global goodness-of-fit index for PLS structural equation modeling. France: HEC School of Management (Oral Communication to PLS Club)

Anderson, J. C., \& Gerbing, S. W. (1988). Structural equation modeling in practice: A review and recommended two-step approach. Psychological Bulletin, 103(3), 411-423.

Anderson, C. (2008, June 28). The end of theory: The data deluge makes the scientific method obsolete. Wired. Retrieved from http://www.wired.com/science/discoveries/magazine/1607/pb_theory

Bagozzi, R. P., \& Yi, Y. (1988). On the evaluation of structural equation models. Journal of the Academy of Marketing Science, 16(1), 74-94.

Beath, C., Becerra-Fernandez, I., Ross, J. and Short, J. (2012), "Finding value in the data explosion", MIT Sloan Management Review, Vol. 53 No. 4, pp. 18-20.

Bersin, J. (2012), "Big data in HR: how to build a world-class Talent Analytics function", available at http://cdn2.hubspot.net/hub/100395/file-342588945-pdf/Josh_Bersin.pdf (accessed 22 March 2015)

Bhatt, G. D., \& Grover, V. (2005). Types of information technology capabilities and their role in competitive advantage: An empirical study. Journal of Management Information Systems, 22(2), 253-277.

Boyd D, Crawford K (2012) Critical questions for big data: provocations for a cultural, technological, and scholarly phenomenon. Inf Commun Soc 15(5):662-679

Boynton A.C., R.W. Zmud, G.C. Jacobs. (1994) The influence of it management practice on it use in large organizations, MIS Quarterly 18 (3): 299-318.

Boynton A.C., R.W. Zmud, G.C. Jacobs, The influence of it management practice on it use in large organizations, MIS Quarterly 18 (3) (1994) 299-318.

Brown, B., Chui, M. and Manyika, J. (2011). "Are you ready for the era of "big data", McKinsey Quarterly, Vol. 4, pp. 24-35. 
JISTEM - Journal of Information Systems and Technology Management

Vol. 14, No. 1, Jan/Apr., 2017 pp. 39-68

ISSN online: $1807-1775$

DOI: $10.4301 / \mathrm{S} 1807-17752017000100003$

Bughin J, Chui M, Manyika J (2010) Clouds, big data, and smart assets: ten tech-enabled business trends to watch. McKinsey Q 56(1):75-86

Chatelin, Y. M., Vinzi, V. E., \& Tenenhaus, M. (2002). State-of-art on PLS modeling through the available software. Jouy-en-Josas: HEC Business School.

Chau P.Y., K.Y. Tam (1997). Factors affecting the adoption of open systems: an exploratory study, MIS Quarterly 21 (1): 1-24.

Chen, H., Chiang, R., \& Storey, V. (2012). Business intelligence and analytics: From big data to big impact.MIS Quarterly, 36(4), 1165-1188.

Cheong, J., \& Park, M. (2005). Mobile internet acceptance in Korea.Internet Research, 15(2), $125-140$.

Chin, W. W., \& Gopal, A. (1995). Adoption intention in GSS: Relative importance of beliefs. DATA BASE, 26(2/3), 42-64.

Chin, W. W., Marcolin, B. L., \& Newsted, P. R. (2003). A partial least squares latent variable modeling approach for measuring interaction effects: Results from a Monte Carlo simulation study and voice mail emotion/adoption study. Information Systems Research, 14(2), 189-217.

Cohen W.M., D.A. Levinthal. (1990). Absorptive capacity: a new perspective on learning an innovation, Administrative Science Quarterly 35 (1): 128-152.

Cohen W.M., D.A. Levinthal, Absorptive capacity: a new perspective on learning an innovation, Administrative Science Quarterly 35 (1) (1990) 128-152.

Davenport TH (b) (2012) The human side of Big Data and high-performance analytics. International Institute for Analytics. pp 1-13

Davenport, T. H. (a) (2012). Enterprise analytics: Optimize performance, process, and decisions through big data. Upper Saddle River, New Jersey: FT Press Operations Management.

Davenport, T. H. and Dyché, J. (2013), "Big data in big companies", available at http://resources.idgenterprise.com/original /AST-0109216_Big_Data_in_Big_Companies.pdf (accessed 13 March 2015).

Davison, A. C., \& Hinkley, D. V. (1997). Bootstrap methods and their application. Cambridge: Cambridge University Press.

DeLone, W., \& McLean, E. (2003). The DeLone and McLean model of information systems success. Journal of Management Information Systems, 19(4), 9-30. 
JISTEM - Journal of Information Systems and Technology Management

Vol. 14, No. 1, Jan/Apr., 2017 pp. 39-68

ISSN online: $1807-1775$

DOI: $10.4301 / \mathrm{S} 1807-17752017000100003$

Demirkan, H. and Delen, D. (2013), "Leveraging the capabilities of service-oriented decision support systems: putting analytics and big data in cloud", Decision Support Systems, Vol. 55 No. 1, pp. 412-421.

Dijcks J-P (2013) Oracle: big data for the enterprise. Redwood Shores, Oracle

Dillon, W. R., \& Goldstein, M. (1984). Multivariate analysis: Methods and applications. New York: Wiley.

Effects Using Partial Least Squares (PLS). Journal of The American Society for Information Science and Technology, 62(1), 100-116.

Efron, B., \& Tibshirani, R. J. (1993). An introduction to the bootstrap. New York: Chapman Hall.

Esteves, J., \& Curto, J. (2013). A risk and benefits behavioral model to assess intentions to adopt big data.Journal of Intelligence Studies in Business, 3(1), 37-46.

Fairhurst, P. (2014), "Big data and HR analytics”, IES Perspectives on HR 2014, pp. 7-13.

Fan J, Han F, Liu H (2014) Challenges of big data analysis. Nat Sci Rev 1(2):293-314

Fichman R.G. (1992). Information technology diffusion: a review of empirical research, Proceedings of the 13th International Conference on Information Systems, December, pp. 195206.

Fornell, C., \& Larcker, D. F. (1981). Evaluating structural equitation models with unobservable variables and measurement errors. Journal of Marketing Research, 18, 39-50.

Forrester (2012) The big deal about big data for customer engagement business: leaders must lead big data initiatives to derive value. Available:http://www.forrester.com/The + Big+Deal+About+Big+Data + For+Customer+Engagement/fulltext/-/ERES72241. Accessed 5 Decenber 2015.

Galbraith, J. (2014), "Organization design challenges resulting from big data", Journal of Organization Design, Vol. 3 No. 1, pp. 2-13. Joreskog, K., \& Sorbom, D. (1993). LISREL. Chicago, IL: VIII Scientific Software.

Gandomi A, Haider M (2015) Beyond the hype: big data concepts, methods, and analytics. Int J Inf Manag 35(2):137-144

Gefen, D., Straub, D., \& Boudreau, M. (2000). Structural equation modeling techniques and regression: Guidelines for research practice. Communications of the Association for Information Systems, 7(7), 1-78.

Gerhardt, B., Griffin, K. and Klemann, R. (2012), "Unlocking value in the fragmented world of big data analytics: how information infomediaries will create a new data ecosystem", available 
JISTEM - Journal of Information Systems and Technology Management

Vol. 14, No. 1, Jan/Apr., 2017 pp. 39-68

ISSN online: $1807-1775$

DOI: $10.4301 / \mathrm{S} 1807-17752017000100003$

at https://www.cisco.com/web/about/ac79/docs/sp/InformationInfomediaries.pdf (accessed 11 March 2015)

Griffith T.L., J.E. Sawyer, M.A. Neale (2003). Virtualness and knowledge in teams: managing the love triangle of organizations, individuals, and information technology, MIS Quarterly 27 (2): 265-287.

Groves, W., Collins, J., Gini, M. and Ketter, W. (2014), "Agent-assisted supply chain management: analysis and lessons learned”, Decision Support Systems, Vol. 57, pp. 274-284.

Gutman, J., (1982). "A Means-End Chain Model based on Consumer Categorization Process," Journal of Marketing, Vol.46, No2, pp.60-78.

Hahn, G. J. and Packowski, J. (2015), “A perspective on applications of In-memory analytics in supply chain management", Decision Support Systems, available at http://dx.doi.org/10.1016/ j.dss. 2015. 01.003 (accessed 10 December 2015).

Hair, J. F., Black, W. C., Babin, B. J., \& Anderson, R. E. (2010). Multivariate data analysis. A global perspective. Upper Saddle River: Pearson.

Hair, J. F., Black, W. C., Babin, B. J., \& Anderson, R. E. (2010). Multivariate data analysis. A global perspective. Upper Saddle River: Pearson.

Harford, T. (2014), "Big data: are we making a big mistake", Financial Times, 8 March, available at http://www.ft.com/cms/s/2/21a6e7d8-b479-11e3-a09a00144feabdc0.html\#axzz2xlNF6IjV (accessed 18 March 2015).

Hazen, B. T., Boone, C. A., Ezell, J. D. and Jones-Farmer, L. A. (2014), "Data quality for data science, predictive analytics, and big data in supply chain management: an introduction to the problem and suggestions for research and applications", International Journal of Production Economics, Vol. 154, pp. 72-80.

Henderson, A. R. (2005). The bootstrap: A technique for data-driven statistics. Using computer-intensive analyses to explore experimental data. Clinica Chimica Acta, 359, 126.

Hendrickson,A.R.,,P.D. (1993). Massey and T.P.Cronan,"On the Test-Retest Reliability of Perceived Usefulness and Perceived Ease of Use Scales,"IS Quarterly,Vol.17,No.2, pp.227-230.

Hulland, J. (1999). Use of partial least squares (PLS), Strategic management research: A review of four recent studies. Strategic Management Journal, 20(4), 195-204.

Iacovou, C. L., Benbasat, I., \& Dexter, A. S. (1995). Electronic data interchange and small organizations: adoption and impact of technology. MIS quarterly, 465-485.

Işık, Ö., Jones, M. C. and Sidorova, A. (2013), "Business intelligence success: the roles of BI capabilities and decision environments", Information \& Management, Vol. 50 No. 1, pp. 13-23. 
JISTEM - Journal of Information Systems and Technology Management

Vol. 14, No. 1, Jan/Apr., 2017 pp. 39-68

ISSN online: $1807-1775$

DOI: $10.4301 / \mathrm{S} 1807-17752017000100003$

Jacobs A (2009) The pathologies of big data. Commun ACM 52(8):36

Jin, X., Wah, B. W., Cheng, X. and Wang, Y. (2015),"Significance and challenges of big data research, Big Data Research, available at http://dx.doi.org/10.1016/j.bdr.2015.01.006 (accessed 11 March 2015).

Kaisler, S., Armour, F., Espinosa, J. A. and Money, W. (2013), "Big data: issues and challenges moving forward", in System Sciences (HICSS) 2013 46th Hawaii International Conference On,pp. 995-1004.

Kotler S., (2003). When enterprises hit the open road: move beyond the silos and let the ideas roll, Teradata Magazine 3 (3)

Kuan, K. K., \& Chau, P. Y. (2001). A perception-based model for EDI adoption in small businesses using a technology-organization-environment framework.Information \& management, 38(8), 507-521.

Kwon, O., Lee, N., \& Shin, B. (2014). Data quality management, data usage experience and acquisition intention of big data analytics.International Journal of Information Management, 34(4), 1-22.

Lohr, S. (2012), "The age of big data", New York Times, 11 Feburary, available at http://www.nytimes.com/2012/02/12/sunday-review/big-datas-impact-in-the-world.html (accessed 11 March 2015).

Malhotra, N. (2010). Marketing research: An applied orientation. Boston: Pearson.

Malhotra, N. (2010). Marketing research: An applied orientation. Boston: Pearson.

Manyika J, Chui M, Brown B, Bughin J, Dobbs R, Roxburgh C, Byers AH (2011) Big data: the next frontier for innovation, competition, and productivity

Mark AB, Laney D (2012) The importance of 'big data': a definition. Gartner, Jun, 21

Mayer-Schönberger, V., \& Cukier, K. (2013) Big data: A revolution that will transform how we work, live and think. New York, NY: Houghton Mifflin Harcourt.

McAfee A, Brynjolfsson E, Davenport TH, Patil DJ, Barton D (2012) Big data: the management revolution. Harv Bus Rev 90(10):61-67.

McAfee, A. and Brynjolfsson, E. (2012). "Big data: the management revolution", Harvard Business Review, Vol. 90 No. 10, pp. 60-68.

McGahan A (2013) Unlocking the big promise of big data.Totman Manag 6(1):53-57.

McGuire, T., Manyika, J. and Chui, M. (2012). "Why big data is the new competitive advantage", Ivey Business Journal, Vol. 76 No. 4, pp. 1-4. 
JISTEM - Journal of Information Systems and Technology Management

Vol. 14, No. 1, Jan/Apr., 2017 pp. 39-68

ISSN online: $1807-1775$

DOI: $10.4301 / \mathrm{S} 1807-17752017000100003$

Mehrtens J, Cragg PB, Mills AM. (2001). A model of Internet adoption by SMEs. Information and Management 2001;39(3):165-76.

Min H, Galle WP. (2003) E-purchasing: profiles of adopters and nonadopters. Industrial Marketing Management;32(3):227-33.

Nonaka I., (1991) The knowledge-creating company, Harvard Business Review 69 (6): 96-104.

Prescott, M. E. (2014), "Big data and competitive advantage at Nielsen", Management Decision, Vol. 52 No. 3, pp. 573-601.

Puschmann, C., \& Burgess, J. (2014). Big Data, Big Questions| Metaphors of Big Data. International Journal of Communication, 8, 20.

Ramamurthy, K., Sen, A., \& Sinha, A. (2008). An empirical investigation of the key determinants of data warehouse adoption. Decision Support Systems, vol. 44, pp: 817-841.

Ringle, C. M., Wende, S., \& Will, A. (2005). SmartPLS 2.0 M3 (beta). University of Hamburg. www.smartpls.de

Robinson, J. P., Shaver, P. R., \& Wrightsman, L. S. (1991). Criteria for scale selection and evaluation. Measures of personality social psychology attitudes. San Diego: Academic Press.

Robinson, J. P., Shaver, P. R., \& Wrightsman, L. S. (1991). Criteria for scale selection and evaluation. Measures of personality social psychology attitudes. San Diego: Academic Press.

Rogers, E.M. (1995).: Diffusion of innovation. New York: Free Press.

Rozados, I. V. and Tjahjono, B. (2014), "Big data analytic in supply chain management: trends and related research", in 6th International Conference on Operation and Supply Chain Management, Bali.

Sambamurthy V., R.W. Zmud (1999). Arrangements for information technology governance: a theory of multiple contingencies, MIS Quarterly 23 (2): 261-290.

Saunders CS, Clark S. EDI adoption and implementation: a focus on interorganizational linkages. Information Resources Management 1992;5(1):9-19.

Segars, A. H., \& Grover, V. (1993). Re-examining perceived ease of use and usefulness: A confirmatory factor analysis. MIS Quarterly, 17(4), 517-529.

Sharma A., Citurs A., and Konsynski B, (2007), "Strategic and Institutional Perspectives in the Adoption and Early Integration of Radio Frequency Identification (RFID)", Proceedings of the 40th Hawaii International Conference on System Sciences - 2007. 
JISTEM - Journal of Information Systems and Technology Management

Vol. 14, No. 1, Jan/Apr., 2017 pp. 39-68

ISSN online: $1807-1775$

DOI: $10.4301 / \mathrm{S} 1807-17752017000100003$

Shin, D. (2013). User centric cloud service model in public sectors.Government Information Quarterly, 30(2), 194-203.

Shin, D. (2014). A socio-technical framework for internet-of-things design.Telematics and Informatics, 31(4), 322-339.

Shin, D. H. (2015). Demystifying big data: Anatomy of big data developmental process. Telecommunications Policy.

Sun EW, Chen YT, Yu MT (2015) Generalized optimal wavelet decomposing algorithm for big financial data. Int J Prod Econ. doi:10.1016/j.ijpe.2014.12.033

Swanson, E. B. (1994). Information systems innovation among organizations.Management science, 40(9), 1069-1092.

Tambe, P. (2014), "Big data investment, skills, andfirm value", Management Science, Vol. 60 No. 6, pp.1452-1469.

Tenenhaus, M., Vinzi, V. E., Chatelin, Y.-M., \& Lauro, C. (2005). PLS path modeling. Computational Statistics and Data Analysis, 48(1), 159-205.

The Whitehouse. (2014), "Big data: seizing opportunities, preserving values",

Tinati, R., Halford, S., Carr, L., \& Pope, C. (2014). Big data: Methodological challenges and approaches for sociological analysis.Sociology, 48(1), 23-39.

Wamba SF, Akter S, Edwards A, Chopin G, Gnanzou D (2015) How'big data'can make big impact: findings from a systematic review and a longitudinal case study. Int $\mathrm{J}$ Prod Econ. doi:10.1016/j.ijpe.2014.12.031.

Weinberger, David (2012). Too big to know: Rethinking knowledge now that the facts aren't the facts, experts are everywhere, and the smartest person in the room is the room. New York, NY: Basic Books.

Wetzels, M., Odekerken-Schröder, G., \& van Oppen, C. (2009). Using PLS path modeling for assessing hierarchical construct models: Guidelines and empirical illustration. MIS Quarterly, 33(1), 177-195.

Woerner, S. L. and Wixom, B. H. (2015), "Big data: extending the business strategy toolbox",Journal of Information Technology, available at http://www.palgravejournals.com/jit/journal/vaop/ncurrent/full/jit201431a.html (accessed 15 December 2015). 